\title{
Inbreeding and the incidence of childhood genetic disorders in Karnataka, South India
}

\author{
A RADHA RAMA DEVI, N APPAJI RAO, AND A H BITTLES* \\ From the Indian Council for Medical Research Centre for Biomedical Research, and the Department of $\vec{P}$ \\ Biochemistry, Indian Institute of Science, Bangalore 560012, India; and *the Department of Anatomy and \\ Human Biology, King's College, London WC2R 2 LS.
}

SUMMARY Consanguineous marriages are strongly favoured among the populations of South India. In a study conducted on 407 infants and children, a total of 35 genetic diseases wasi diagnosed in 63 persons: 44 with single gene defects, 12 with polygenic disorders, and seven with Down's syndrome. The coefficient of inbreeding of the total study group, $F=0 \cdot 0414$, was significantly higher than that previously calculated for the general population, $F=0 \cdot 0271$, and autosomal recessive disorders formed the largest single disease category diagnosed. The resultt suggest that long term inbreeding may not have resulted in appreciable elimination of recessive lethals and sub-lethals from the gene pool.

Among the Dravidian populations of the four southern states of India, Andhra Pradesh, Karnataka, Kerala, and Tamil Nadu, consanguineous marriages are strongly favoured. ${ }^{1-4}$ The actual levels of consanguinity observed vary considerably, ${ }^{56}$ for example, from 4.5 to $61.3 \%$ depending on factors such as religion, ${ }^{78}$ caste, ${ }^{910}$ and socioeconomic status, ${ }^{11}{ }^{12}$ but generally inbreeding is most common in the more traditional, rural communities. ${ }^{46}$ In contrast to some inbreeding isolates reported from other parts of the world, consanguinity in South India does not result from a shortage of potential marital partners. At the last Census of India conducted in 1981, the combined population of the four southern states exceeded 164 millions, and consanguineous marriages are also common in the contiguous portion of Maharashtra. ${ }^{13}$

While inbreeding at this level might reasonably be expected to result in large numbers of infant and childhood disorders due to the expression of rare single lethal and sub-lethal recessives or polygenic combinations of rare recessives, it has been proposed that the long term practice of inbreeding would have led to a marked reduction in the number of deleterious genes in the gene pool. ${ }^{14}$ Evidence in support of this hypothesis has been claimed in large scale prospective and retrospective studies on fertility and infant mortality in Tamil Nadu. ${ }^{15-17}$ However,

Received for publication 27 February 1986

Revised version accepted for publication 15 April 1986 contrary conclusions were reached in recent surveys in Karnataka on childhood mortality ${ }^{18}$ and on the incidence of aminoacidopathies in newborns. ${ }^{19}$ The्ष aim of the present study was to obtain baseline information on the prevalence of genetic disorder $\overrightarrow{\widehat{S}}$ among a group of children under hospital invest $\vec{\beta}$ gation in Karnataka, and to determine the nature of the relationship(s) between the disorders diag nosed and the common preference for consars guineous marriages.

\section{Subjects}

A total of 407 infants and children from the cities of Bangalore and Mysore was studied during the years 1982 and 1984 . They represented 394 sibships; th male/female ratio was 1.22 and their ages ranged. from 15 days to 14 years (mean 2.89 years). In just over half of the cases (211/407), the patients were referred to the Centre for Biomedical Research wit a preliminary diagnosis suggestive of some form of genetic disorder. The remainder (196/407), who were all recruited as hospital inpatients, had no specifie symptoms (table 1). The mean size of the familie from which the patients were drawn was $2.6 \%^{\circ}$ liveborns (SD 1.63) with 2.35 living children (SDP $1 \cdot 43$ ). To put these figures into perspective, the meafo total marital fertility for Karnataka in 1978 was 3. P in rural areas and 3.0 for urban groups. ${ }^{20}$ Th\& religious profile of the patients and their coefficients 
TABLE 1 Reasons for referral/investigation.

\begin{tabular}{lr}
\hline & No \\
\hline Suspected genetic disorder & 60 \\
Stunted growth/delayed milestones & 36 \\
Convulsions & 10 \\
Delayed learning/mental retardation & 25 \\
Hearing/speech defect & 25 \\
Eye defect & 17 \\
Skeletal abnormalities & 7 \\
Diplegia/hemiplegia & 5 \\
Gastrointestinal symptoms & 10 \\
Abnormal hair colour & 5 \\
Skin complaints & 4 \\
Poor maternal obstetric history & 7 \\
'Sick child' & 192 \\
Others & 4 \\
Total & 407 \\
\hline
\end{tabular}

TABLE 2 Religious profile and consanguinity classes of the study group.

\begin{tabular}{lrrrrrrrr}
\hline \multicolumn{7}{c}{ Coefficient of inbreeding $(F)$} \\
\cline { 2 - 8 } Religion & 0 & $<0.0156$ & 0.0156 & 0.0625 & 0.125 & Unknown & Totals \\
\hline Hindu & 157 & 11 & 17 & 41 & 88 & 27 & 349 \\
Muslim & 23 & 1 & 1 & 12 & 3 & 3 & 43 \\
Christian & 11 & 0 & 0 & 0 & 0 & 1 & 12 \\
Others & 1 & 0 & 0 & 0 & 0 & 0 & 1 \\
Unknown & 0 & 0 & 0 & 0 & 0 & 2 & 2 \\
Totals & 192 & 12 & 18 & 61 & 91 & 33 & $4(17$ \\
\hline
\end{tabular}

of inbreeding $(F)$ are shown in table 2 . The $F$ values refer to consanguinity only in the present generation as, due to a lack of written records, no information was available on inbreeding levels in previous generations.

\section{Methods}

All patients were examined clinically on an individual basis and radiological investigations were requested when deemed necessary. Finger prick or toe prick blood samples and random urine specimens were routinely collected. The urines were first examined for evidence of inborn errors of metabolism using basic side room tests. ${ }^{21}$ Urinary amino acids, standardised on a creatinine equivalent, were analysed by circular chromatography. ${ }^{22}$ Blood amino acids were screened by a semiquantitative thin layer chromatographic technique $e^{23}$ followed, where appropriate, with quantitative assay on venepuncture samples using an automatic amino acid analyser. Evidence of reducing substances in the urine was further investigated by descending paper chromatography with aniline staining. ${ }^{24}$ Excess mucopolysaccharides in the urine were detected with an Alcian blue spot test ${ }^{25}$; in such cases the specific, abnormal constituent(s) was identified via cellulose acetate electrophoresis. ${ }^{26}$ Where possible, specific blood product or enzyme assays were employed to confirm diagnoses, for example, in congenital hypothyroidism, glucose-6phosphate dehydrogenase deficiency, galactosaemia, and Wilson's disease. In a minority of cases, examples being maple syrup urine, tyrosinaemia, and alcaptonuria, the requisite assay methods were unavailable. The clinical diagnoses of Down's syndrome were confirmed by cytogenetic analysis, using phytohaemagglutinin stimulated blood cultures and trypsin banding.

\section{Results}

A total of 35 different genetic diseases was identified in 63 persons. The numbers and types of each disorder diagnosed in the study group are shown in table 3 and the specific disease classifications, based on Stanbury et $\mathrm{al}^{27}$ and McKusick, ${ }^{28}$ are presented in tables 4 and 5 . For a number of disorders the absence of written records or inadequate pedigree data or both made determination of the precise mode of inheritance impossible. In addition to the single gene and polygenic disorders listed in tables 4 and 5, seven chromosomal anomalies were diagnosed, all being cases of Down's syndrome.

The role of inbreeding in the aetiology of the genetic disorders is clearly shown in table 6 . The coefficient of inbreeding of the study group $(\mathrm{F}=$ 0.0414 ) was significantly greater than that previously determined for the population as a whole $(\mathrm{F}=$ $0 \cdot 0271) .{ }^{18}$ The further rise in the coefficients of inbreeding of all single gene defects $(\mathrm{F}=0.0513)$ and those with an autosomal recessive mode of inheritance only $(F=0.0625)$ confirm the deleterious effect of consanguinity. If the 44 subjects with single gene defects $(\mathrm{F}=0.0513)$ and the 12 with polygenic disorders $(F=0.0638)$ are excluded from the study group, the coefficient of inbreeding for the remaining patients is $F=0.0397$. Since this is significantly higher than the value for the general population

TABLE 3 Genetic disorders diagnosed in the study population.

\begin{tabular}{lcl}
\hline Type & Number & Percentage of total \\
\hline Single gene defects & & \\
Autosomal dominant & 11 & $2 \cdot 7$ \\
Autosomal recessive & 24 & $5 \cdot 9$ \\
X linked & 5 & $1 \cdot 2$ \\
$\quad$ Uncertain & 4 & $1 \cdot 0$ \\
Chromosomal anomalies & 7 & $1 \cdot 7$ \\
Polygenic disorders & 12 & $2 \cdot 9$ \\
Total & 63 & $15 \cdot 5$ \\
\hline
\end{tabular}


TABLE 4 Single gene defects.

\begin{tabular}{|c|c|c|}
\hline & $\begin{array}{l}\text { Mode of } \\
\text { inheritance }\end{array}$ & $\begin{array}{l}\text { No of } \\
\text { cases }\end{array}$ \\
\hline \multicolumn{3}{|l|}{ Disorders of metabolism } \\
\hline \multicolumn{3}{|l|}{ Amino acids } \\
\hline Phenylketonuria & AR & 1 \\
\hline Tyrosinaemia & $\mathrm{AR}$ & 2 \\
\hline Histidinaemia & $\mathrm{AR}$ & 3 \\
\hline Branched chain aminoacidaemia & $\mathrm{AR}$ & 3 \\
\hline Congenital hypothyroidism & $\mathrm{AR}$ & 1 \\
\hline Alkaptonuria & $\mathrm{AR}$ & 1 \\
\hline \multicolumn{3}{|l|}{ Carbohydrate } \\
\hline Galactosaemia & AR & 1 \\
\hline Glycogen storage, type 1 & AR & 1 \\
\hline \multicolumn{3}{|l|}{ Purine and pyrimidine } \\
\hline Lesch-Nyhan syndrome & $\mathrm{X}$ & 1 \\
\hline \multicolumn{3}{|l|}{ Porphyrin and haem } \\
\hline Acute intermittent porphyria & $\mathrm{AD}$ & 3 \\
\hline \multicolumn{3}{|l|}{ Blood } \\
\hline Glucose-6-phosphate dehydrogenase deficiency & $\mathrm{x}$ & 1 \\
\hline \multicolumn{3}{|l|}{ Metal } \\
\hline Wilson's disease & AR & 2 \\
\hline \multicolumn{3}{|l|}{ Lysosomal enzymes } \\
\hline \multicolumn{3}{|l|}{ Mucopolysaccharidoses: } \\
\hline Type III Sanfilippo & AR & 1 \\
\hline Type IV Morquio & AR & 3 \\
\hline \multicolumn{3}{|l|}{ Connective tissue and muscle } \\
\hline Marfan syndrome & $\mathrm{AD}$ & 2 \\
\hline Duchenne muscular dystrophy & $\mathrm{X}$ & 1 \\
\hline \multicolumn{3}{|l|}{ Transport } \\
\hline Familial hypophosphataemic rickets & $\mathrm{X}$ & 2 \\
\hline Vitamin $\mathrm{D}$ dependent rickets & AR & 1 \\
\hline Indicanuria & AR & 1 \\
\hline Renal glycosuria & AR & 1 \\
\hline \multicolumn{3}{|l|}{ Miscellaneous } \\
\hline Retinitis pigmentosa & $?$ & 4 \\
\hline Klippel-Feil syndrome & $\mathrm{AD}$ & 1 \\
\hline Bardet-Biedl syndrome & AR & 1 \\
\hline Congenital biliary atresia & $\mathrm{AR}$ & 1 \\
\hline Syndactyly & $?$ & 1 \\
\hline Polydactyly & $?$ & 1 \\
\hline Deaf-mutism & $?$ & 3 \\
\hline Total & & 44 \\
\hline
\end{tabular}

TABle 5 Polygenic disorders.

\begin{tabular}{lc}
\hline Type & No of cases \\
\hline Congenital heart defects & 3 \\
Microcephaly & 3 \\
Hydrocephalus & 1 \\
Multiple skeletal abnormalities, hip dislocation. & 1 \\
$\quad$ cleft lip and palate & 2 \\
Cleft lip \pm palate & 1 \\
Congenital posturethral valves & 1 \\
Juvenile onset diabetes & 12 \\
Total & \\
\hline
\end{tabular}

TABLE 6 Inbreeding levels of the study population.

\begin{tabular}{lll}
\hline & $\begin{array}{l}\text { Percentage } \\
\text { inbreeding }\end{array}$ & $\begin{array}{l}\text { Coefficient of } \\
\text { inbreeding }(F)\end{array}$ \\
\hline Total study population & $48 \cdot 7$ & $0 \cdot 0414$ \\
Single gene disorders only & $45 \cdot 2$ & $0 \cdot 0513$ \\
Autosomal recessive disorders only & $60 \cdot 9$ & $0 \cdot 0625$ \\
General newborn population & $32 \cdot 2$ & $0 \cdot 0271$ \\
\hline
\end{tabular}

$(\mathrm{F}=0.0271)$, it is strongly suggestive of a sizeab展 recessive gene contribution to the symptoms of man $\overrightarrow{7}$ of the patients in whom no diagnosis was possible

\section{Discussion}

The overwhelming majority of childhood referrals im South India remains infectious or nutritional in origin. Against the background of this large enviror? mental burden, it may be impossible to detect statistically significant consanguinity related effect for example, on infantile mortality ${ }^{15}{ }^{16}$ or mentä retardation. ${ }^{29}$ This has encouraged belief in the unproven but widely held assumption that high rate of inbreeding over multiple generations necessarit would have resulted in appreciable elimination कึ deleterious recessive genes. ${ }^{14}$ The theoretical ang practical limitations associated with this hypothesis have recently been reviewed ${ }^{18}$ and the results of the present survey, in conjunction with other repors from different parts of southern India, ${ }^{30-32}$ indicate the continued existence in the gene pool of a wides range of lethal and sub-lethal genes.

Unfortunately, extrapolation from the current study to provide estimates for the incidence of specific genetic disorders in the total population not feasible as, besides the relatively small number of subjects investigated, their symptoms and referrat patterns were notably heterogeneous (table 1). If addition, the testing protocol was strongly biased towards the detection of disorders with recognisable biochemical abnormalities, resulting in a deficit other types of cases, for example, chromosomal anomalies, which would have been referred to a alternative local centre. As malaria has been and, a varying extent, is still endemic in South India haemoglobinopathies could be predicted to prevalent; their absence from table 4 reflects th limited range of laboratory tests currently available rather than the probable incidence of these conditions in the population.

Nevertheless, the study confirms that many genetie. disorders do exist in the Karnatakan population of Therefore, the conclusion which must be drawn is that as environmental causes of childhood morbidip and mortality decline in the region, so the proportiowp of diseases with an exclusive or partial genet aetiology will increase, a phenomenon previous described in the United Kingdom. ${ }^{33}{ }^{34}$

The authors gratefully acknowledge the cooperatio of clinicians in Bangalore and Mysore in the referro of patients, and the collaboration of Drs $P$ R Krishnaswamy and B S Sridhara Rama Rao, an Professors Manorama Thomas and $\mathrm{H}$ Naruse 遇 
providing confirmatory laboratory diagnoses. Generous financial assistance was given during the course of the study by the Indian Council for Medical Research, The British Council, the Overseas Development Administration (UK), and the Royal Society, London.

\section{References}

' Sanghvi LD. Inbreeding in rural areas of Andhra Pradesh Indian J Genet 1966:26A:351-65.

2 Radha Rama Devi A. Appaji Rao N. Bittles AH. Inbreeding in the state of Karnataka. South India. Hum Hered 1982:32:8-10.

3 Kumar S. Pai RA. Swaminathan MS. Consanguineous marriages and the genetic load due to lethal genes in Kerala. Ann Hum Genet 1967:31:141-5.

+ Rao PSS. Inbaraj SG. Inbrecding in Tamil Nadu. South India. Soc Biol 1977:24:281-8.

5 Ray AK. Nature, amount and extent of consanguinity among two South Indian castes. J Hered 1979:70:281-2.

- Centerwall WR. Savarinathan G. Mohan LR. Booshanan V. Zachariah M. Inbreeding patterns in South India. Soc Biol 1969:16:81-91.

7 Asha Bai PV. Jacob John T. Subramaniam VR. Reproductive wastage and developmental disorders in relation to consanguinity in South India. Trop Geogr Med 1981:33:275-80.

* Rao PSS. Religion and the intensity of inbreeding in Tamil Nadu. South India. Soc Biol 1983:30:413-22.

"Rao PSS. Inbaraj SG. Kaliaperumal VG. An epidemiological study of consanguinity in a large South Indian town. Indian J Med Res 1971:59:294-301.

1" Papa Rao A. Rami Reddy V. Inbrecding among threc endogamous groups in a multicaste village of Andhra Pradesh. India. Soc Biol 1983:30:109-11.

"Dronamraju KR. Meera Khan P. A study of Andhra marriages: consanguinity. caste, illiteracy. and bridal age. Acta Genet 1963:13:21-9.

12. Venugophal Rao V. Murty JS. Selection intensitics and inbreeding among some caste groups of Andhra Pradesh, India. Soc Biol 1984:31:114-9.

${ }^{13}$ Malhotra KC. Inbreeding among Dhangar castes of Maharashtra. India. J Biosoc Sci 1979:11:397-409.

${ }^{14}$ Sanghvi LD. Inbreeding in India. Eugen Quart 1966:13:291-301.

15 Rao PSS. Inbaraj SG. Inbreeding effects on human reproduction in Tamil Nadu of South India. Ann Hum Genet 1977:41:87-98.

it Rao PSS. Inbaraj SG. Trends in human reproductive wastage in relation to long-term practice of inbreeding. Ann Hum Genet 1979:42:401-13.

17 Rao PSS. Inbaraj SG. Inbreeding effects on fertility and sterility in southern India. J Med Genet 1979:16:24-31.
${ }^{1 \times}$ Bittles AH. Radha Rama Devi A. Savithri HS. Rajeswari Sridhar. Appaji Rao N. Inbrecding and post-natal mortality in South India: effects on the gene pool. J Genet 1985:64:135-42.

${ }^{14}$ Bittles AH. Radha Rama Devi A. Venkat Rao S. Appaji Rao N. A newborn screening programme for the detection of aminoacid disorders in South India. Biochem Rev 1982:LII:20-4.

21) Vital Statistics Division. Office of the Registrar General. India. Levels, trends and differentials in fertility. New Delhi: Ministry of Home Affairs. 1982

21 Buist NRM. Set of simple side-room urine tests for the detection of inborn errors of metabolism. Br Med J 1968:ii:745-9.

22 Giri KV, Radhakrishnan AN, Vaidyanathan CS. Some factors influencing the quantitative determination of aminoacids separated by circular paper chromatography. Anal Chem 1952:24: $1677-8$.

23 Ircland JT, Read RA. A thin layer chromatographic method for use in neonatal screening to detect excess aminoacidaemia. Ann Clin Biochem 1972:9:129-32.

24 Varley H. Practical clinical biochemistry. London: Heinemann. 1964:64-9.

25 Berry HK. Spinanger J. A paper spot test useful in the study of Hurler's syndrome. J Lab Clin Med 1960:55:136-8.

26 Lewis PW. Kennedy JF. Raine DN. Investigation of urinary glycosaminoglycans in the mucopolysaccharidoses. Biochem Soc Trans 1973:1:844-6.

27 Stanbury JB, Wyngaarden JB. Frederickson DS. Goldstein JL. Brown MS. eds. The metabolic basis of inherited disease, 5th ed. New York: McGraw-Hill, 1983.

${ }^{2 \times}$ McKusick VA. Medelian inheritance in man. 6th ed. Baltimore: Johns Hopkins University Press. 1983.

${ }^{29}$ Sridhara Rama Rao BS, Narayanan HS. Consanguinity and familial mental retardation. $J$ Med Genet 1976:13:27-9.

30) Sridhara Rama Rao BS, Subhash MN, Narayanan HS. Metabolic anomalies detected during a systematic biochemical screening of mentally retarded cases. Indian $J$ Med Res 1977:65:241-7.

${ }^{31}$ Dhareshwar SS. Ambani LM. Suchak RH. Danthi V. Inborn errors of metabolism in acutely sick children. Indian J Med Res 1982:76:716-22.

32 Uma SM, Jyothy A. Reddy PP. Reddi OS. Aminoacidopathics in Andhra Pradesh; report of a screening programme. $J$ Inher Metab Dis 1982:5:211-4.

${ }_{33}$ Carter CO. Changing patterns in the causes of death at The Hospital for Sick Children. Great Ormond Street J 1956:11:65-8.

${ }^{34}$ Roberts DF. Chavez J. Court SDM. The genetic component in child mortality. Arch Dis Child 1970;45:33-8.

Correspondence and requests for reprints to $\mathrm{Dr} \mathrm{A} \mathrm{H}$ Bittles, Department of Anatomy and Human Biology, King's College London, Strand, London WC2R 2LS. 